\title{
Sewage Pollution in Central India
}

\author{
Khageshwar Singh Patel ${ }^{1}$, Nohar Singh Dahariya ${ }^{1}$, Suryakant Chakradhari' ${ }^{1}$, \\ Pravin Kumar Sahu', Keshaw Prakash Rajhans', Shobhana Ramteke1, \\ Lesia Lata², Huber Milosh² \\ ${ }^{1}$ School of Studies in Chemistry/Environmental Science, Pt. Ravishankar Shukla University, Raipur, India \\ ${ }^{2}$ Department of Soil Science/Geology, Maria Curie-Skłodowska University, Lublin, Poland \\ Email: patelks55@hotmail.com
}

Received 27 July 2015; accepted 4 September 2015; published 7 September 2015

Copyright (C) 2015 by authors and Scientific Research Publishing Inc.

This work is licensed under the Creative Commons Attribution International License (CC BY).

http://creativecommons.org/licenses/by/4.0/

(c) (7) Open Access

\begin{abstract}
Raipur is a fast growing city in central India due to being commercial centre for the steel, cement and forest products of the country. Large quantity ( $\approx 300$ million lit/day) of untreated sewage waste water is discharged into seven reservoirs located in the city. Sewage carries excessive nutrients, heavy metals, organics, bacteria, yeast and fungi by leaking contents into the drinking water which cause acute health problems, ranging from common diarrhoea to deadly diseases such as hepatitis, cholera, typhoid fever, etc. Therefore, in this work, the microbial and chemical contamination of sewage waste of Raipur city, Chhattisgarh, India is described.
\end{abstract}

\section{Keywords}

Nutrients, Heavy Metals, Microbes, Toxicities

\section{Introduction}

Sewage is transported by water wastes resulting mainly from human activities such as washing, cooking, sanitation, commerce, industry, agriculture and surface runoff, etc. [1]. The contaminated sewage water discharged into water reservoirs is one of the main culprits for spread of water borne diseases, air pollution and climate change [2]. Sewage wastes are contaminated with heavy metals, surfactants, toxic organic compounds, bacteria, fungi, parasites, and viruses that can cause intestinal, lung, and other infections [3]-[29]. About 60 percent of urban deaths in India are due to the lack of safe drinking water facilities. Further deaths due to water borne diseases are second only to malnutrition. In present study, the microbial and physicochemical characteristics of the sewage waste of a vast growing city, Raipur (capital, Chhattisgarh state, India) are described.

How to cite this paper: Patel, K.S., Dahariya, N.S., Chakradhari, S., Sahu, P.K., Rajhans, K.P., Ramteke, S., Lata, L. and Milosh, H. (2015) Sewage Pollution in Central India. American Journal of Analytical Chemistry, 6, 787-796. 


\section{Material and Methods}

\subsection{Study Area}

Raipur city is experiencing rapid growth with corresponding increase of economic and commercial activities in an unsustainable order. The city is being the commercial center for steel, cement and forest products. More than two million people living over $\approx 1000 \mathrm{~km}^{2}$ area discharges $\approx 300$ million L/day waste flowing into seven open reservoirs constructed in the city, Figure 1 . The area of sewage sinks was ranged from $2-4 \mathrm{~km}^{2}$. Every year, several people are died due to outbreak of waterborne diseases i.e. jaundice, fatal diarrhea, dysentery, hepatitis, cholera, typhoid fever, etc. in every summer by mixing of the municipal waste with the drinking water.

\subsection{Sample Collection}

The composite water sample $(100 \times 5 \mathrm{~mL}$ from five points of each location) was collected into sterile glass bottles (500 mL) in April 2015 as prescribed in the literature [30]. The pH, electrical conductivity (EC), dissolved oxygen (DO) and reduction potential (RP) values of the water were measured at spot by Hanna made sensors. The total hardness and alkalinity values were determined by the titration methods. One kilogram of the top composite sewage sludge from five points of each location $(0-10 \mathrm{~cm})$ was taken from seven reservoirs in April 2015 by a stainless steel spoon and stored in a glass jar [31]. Samples were transported to the laboratory and immediately stored in a freezer.
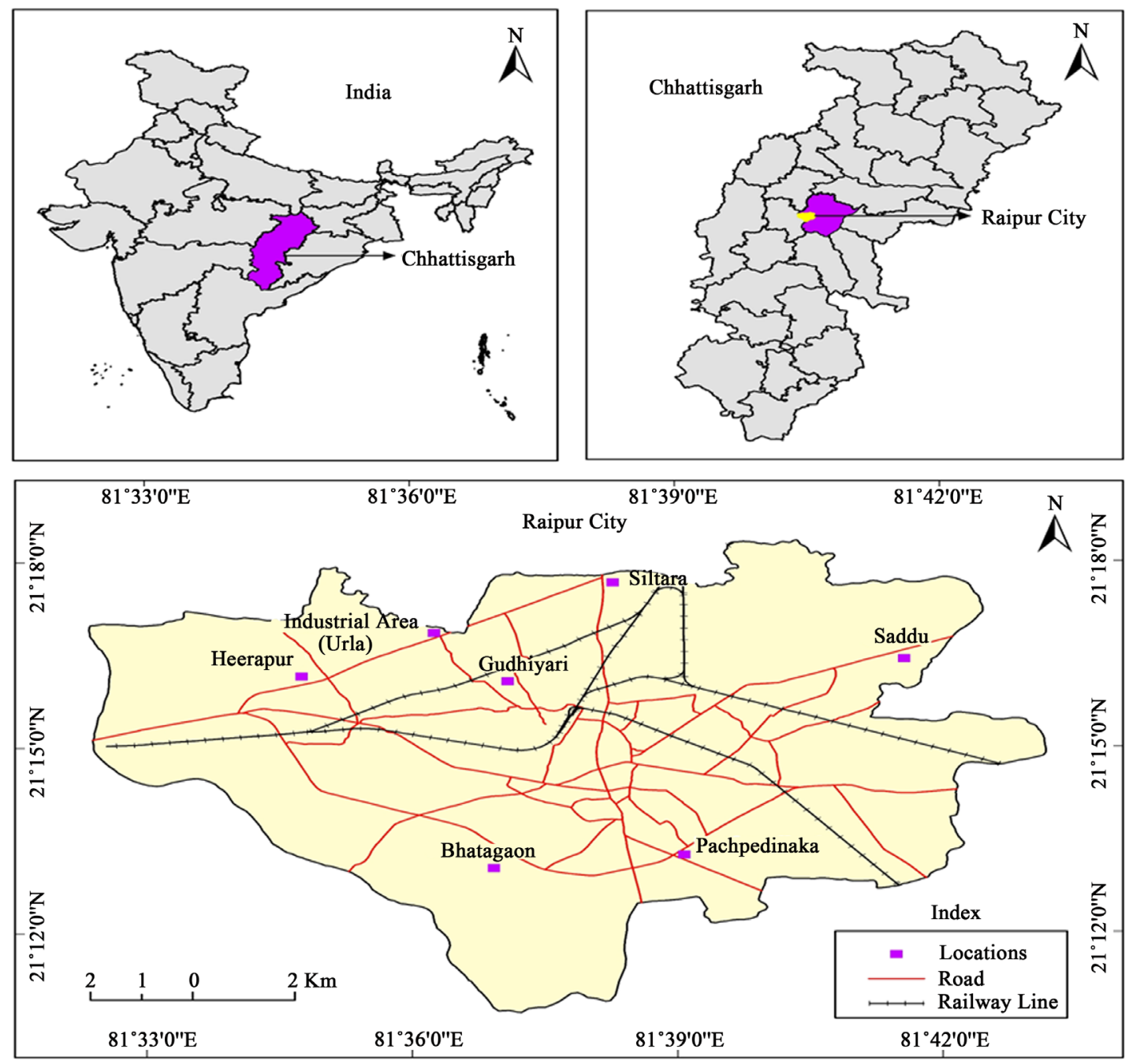

Figure 1. Representation of sampling locations in Raipur city, India. 


\subsection{Analysis}

\subsubsection{Analysis of Microbe}

The microbes i.e. TBC (total bacterial count, all aerobic species of bacteria), pseudomonas, E. coli or yeast + fungi were detected by the bactaslyde (presterilized slide, coated with specially developed media of lactose and indicator) method established by Rakiro Pvt. Ltd. [32]. The slide no. BS-101, BS-102 and BS-103 were used for detection of $E$. coli + TBC, pseudomonas + TBC and yeast-fungi + TBC, respectively. The packed slide was opened, plunged into the test liquid vertically for 20 - 25 sec. The slide was shaken 3 - 4 times gently to remove the excess water by putting back into the tube with tight closing. The bactaslyde was incubated for $24 \mathrm{hrs}$ at $37^{\circ} \mathrm{C}$ for development of colonies. After incubation, the density of the colonies grown on the slide was compared with the standard chart provided. The TBC, pseudomonas, E. coli, and yeast or fungi were marked by dark red colored colonies, respectively, Figure 2. The Salmonella bacteria in the water were detected by the pouch pack (i.e. containing organics and sulfite material) method [32]. The content (10 g) of two pouches was added into a $150-\mathrm{mL}$ sterilized bottle filled with $100 \mathrm{~mL}$ of contaminated water, and incubated for $24 \mathrm{hrs}$ at $37^{\circ} \mathrm{C}$. The light blue color of the solution was turned into dark black in presence of Salmonella species, Figure 3.

\subsubsection{Analysis of Inorganic Species}

The sample was filtered through glass fibre filter $(0.45 \mu \mathrm{m})$ for analysis of ions and metals. The $\mathrm{F}^{-}$content was analyzed by using Metrohm-720 ion meter using the fluoride selective electrode.

The Dionex chromatography DX120 equipped with anion separation columns (AS9-HC, $250 \times 4 \mathrm{~mm}$ ), cation separation column (CS12A, $250 \times 4 \mathrm{~mm})$ and conductivity detector was used for analysis of the ions (i.e. $\mathrm{Na}^{+}$, $\mathrm{K}^{+}, \mathrm{Cl}^{-}, \mathrm{NO}_{3}^{-}, \mathrm{SO}_{4}^{2-}, \mathrm{Mg}^{2+}$ and $\mathrm{Ca}^{2+}$ ).

A $0.25 \mathrm{~g}$ of the sample was digested with acids $\left(3 \mathrm{~mL} \mathrm{HCl}\right.$ and $\left.1 \mathrm{~mL} \mathrm{HNO}_{3}\right)$ in a closed system with $\mathrm{P} / \mathrm{T}$ MARS CEM (Varian Company) microwave oven for use of metal analysis. The Varian ICP-OES-700-ES series was used for monitoring of metals (i.e. $\mathrm{Cr}, \mathrm{Fe}, \mathrm{Mn}, \mathrm{Ni}, \mathrm{Cu}, \mathrm{Zn}$ and $\mathrm{Pb}$ ) in the extract. The GF-AAS SpectrAA 220 Zeeman was used for the analysis of As, Cd and Hg. The NCS DC 73382 CRM sediment sample was used for the quality control.

\subsubsection{Water Oualitv Index}

For this study, ten parameters i.e. $\mathrm{pH}, \mathrm{EC}, \mathrm{DO}$, hardness, alkalinity, $\mathrm{Mg}, \mathrm{Ca}, \mathrm{Cl}^{-}, \mathrm{NO}_{3}^{-}$and $\mathrm{SO}_{4}^{2-}$ were chosen for computation of water quality index (WQI) by using the standard values recommended by WHO and BIS [22] [23]. The weighed arithmetic method was employed for calculation of the WQI of sewage water bodies with the help of following expression.

$$
W Q I=\sum q_{n} W_{n} / \sum W_{n}
$$

where:

$$
q_{n}=100\left(V_{o}-V_{\text {io }}\right) /\left(V_{s}-V_{\text {io }}\right)
$$

$q_{n}=$ Quality rating of the $n$th water quality parameter;

$V_{n}=$ Estimated value of the $n$th parameter of a given water;

$S_{n}=$ Standard permissible value of the $n$th parameter;

$V_{i o}=$ Ideal value of the $n$th parameter of pure water (i.e., 0 for all other parameters except $\mathrm{pH}$ ) and Dissolved oxygen (7.0 and $14.6 \mathrm{mg} / \mathrm{L}$, respectively);

$W_{n}=$ Unit weight for the $n$th parameter;

$K=$ Proportionality constant.

\section{Results and Discussion}

\subsection{Physical, Chemical and Microbial Characteristic of Sewage Water}

The physical, chemical and microbial characteristics of the water are presented in Tables 1-4. The water was colored with offensive smell. The value of $\mathrm{pH}, \mathrm{EC}, \mathrm{DO}, \mathrm{RP}$, total hardness $\mathrm{(TH}$ ) and alkalinity was ranged from 6.9 - 7.8, 698 - $1520 \mu \mathrm{S} / \mathrm{cm}, 5.2$ - $7.7 \mathrm{mg} / \mathrm{L}, 86$ - $337 \mathrm{mV}, 270$ - $670 \mathrm{mg} / \mathrm{L}$ and 320 - $940 \mathrm{mg} / \mathrm{L}$ with mean value of $7.4 \pm 0.2,1075 \pm 252 \mu \mathrm{S} / \mathrm{cm}, 6.8 \pm 0.6 \mathrm{mg} / \mathrm{L}, 157 \pm 63 \mathrm{mV}, 447 \pm 107 \mathrm{mg} / \mathrm{L}$ and $503 \pm 156 \mathrm{mg} / \mathrm{L}$, respectively. 


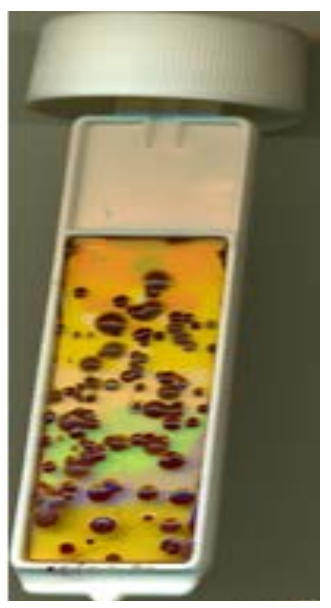

E. coli + TBC

(10 ${ }^{4}$ count $\left./ \mathrm{mL}\right)$

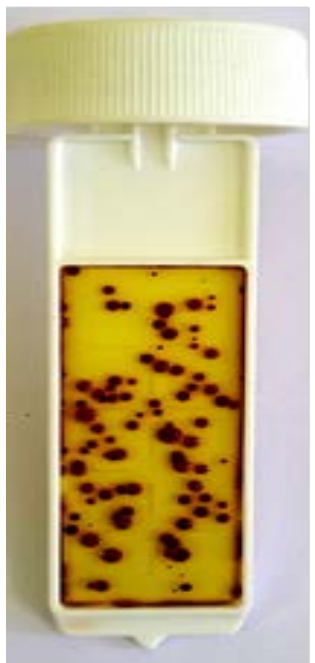

$\mathrm{PM}+\mathrm{TBC}$

$\left(10^{4}\right.$ count $\left./ \mathrm{mL}\right)$

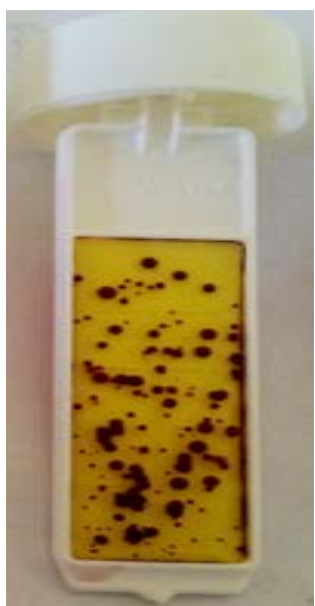

$\mathrm{Y}+\mathrm{F}+\mathrm{TBC}$

$\left(10^{4}\right.$ count $\left./ \mathrm{mL}\right)$

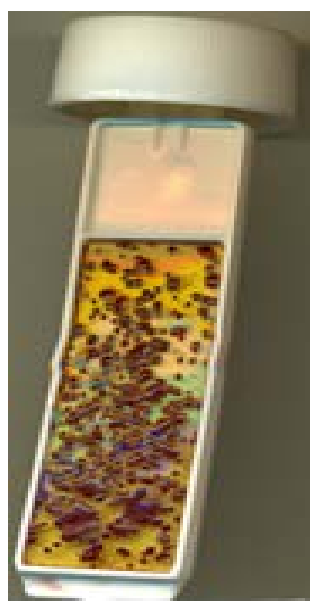

E. coli + TBC

(10 count $/ \mathrm{mL}$ )

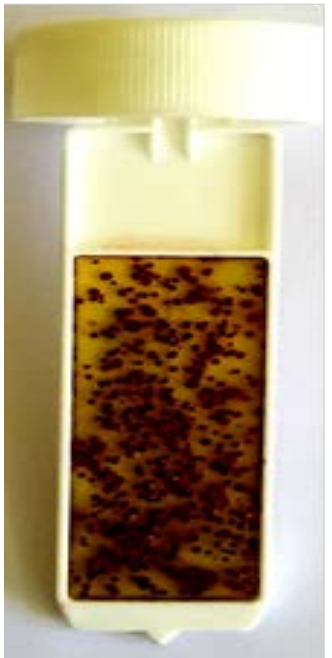

$\mathrm{PM}+\mathrm{TBC}$

(10 count $/ \mathrm{mL}$ )

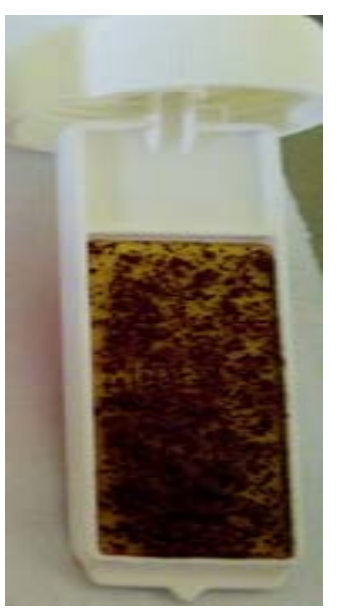

$\mathrm{Y}+\mathrm{F}+\mathrm{TBC}$

$\left(10^{5}\right.$ count $\left./ \mathrm{mL}\right)$

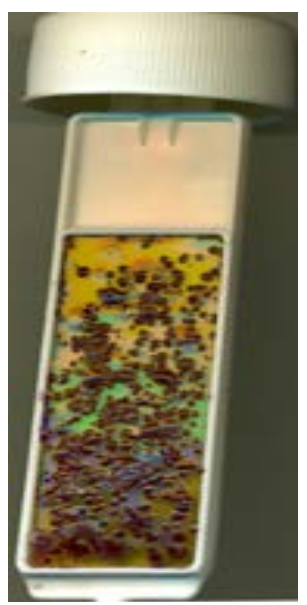

E. coli $+\mathrm{TBC}$

(10 $0^{6}$ count $\left./ \mathrm{mL}\right)$

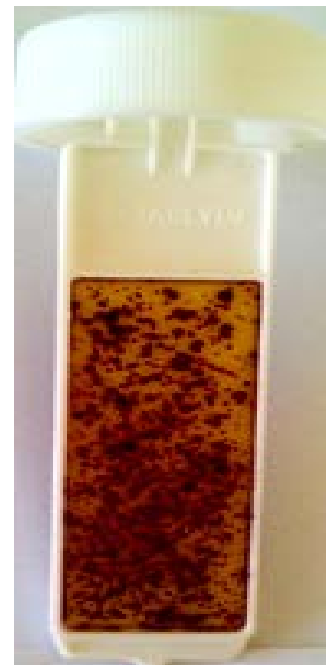

PM + TBC

(10 count $/ \mathrm{mL}$ )

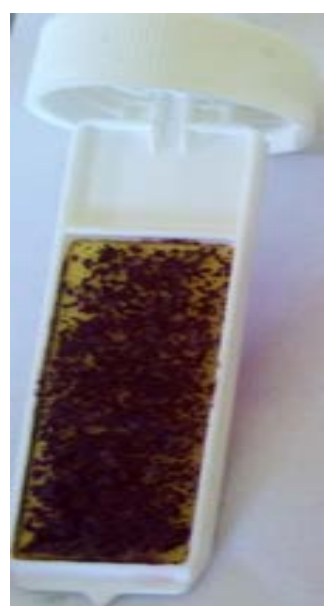

$\mathrm{Y}+\mathrm{F}+\mathrm{TBC}$

$\left(10^{6}\right.$ count $\left./ \mathrm{mL}\right)$

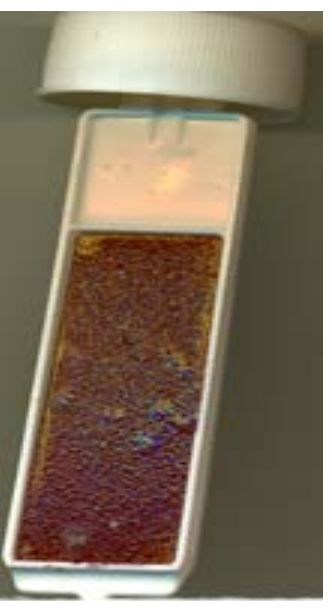

E. coli $+\mathrm{TBC}$

$\left(10^{7}\right.$ count $\left./ \mathrm{mL}\right)$

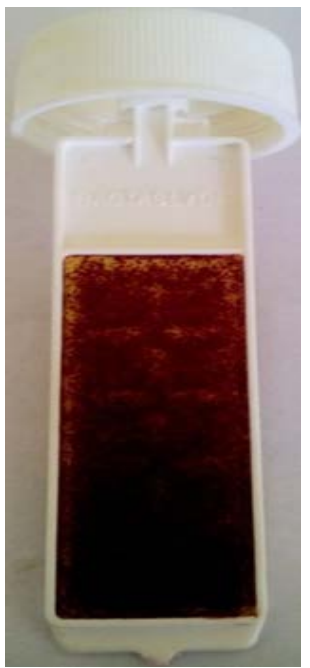

$\mathrm{PM}+\mathrm{TBC}$

(10 $10^{7}$ count $/ \mathrm{mL}$ )

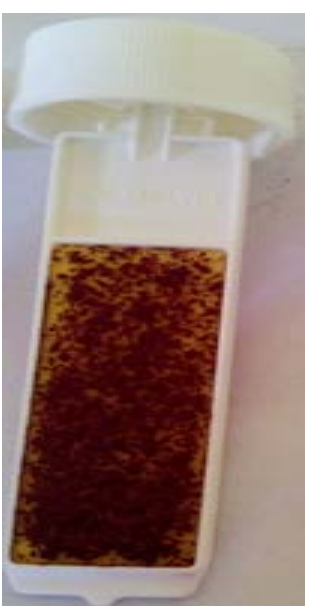

$\mathrm{Y}+\mathrm{F}+\mathrm{TBC}$

(10 count $/ \mathrm{mL})$

Figure 2. Bactaslyde for microbes (1 colony of microbe $=10^{2}$ count microbe), $\mathrm{TBC}=$ Total bacterial count, $\mathrm{PM}=$ Pseudomonas, $\mathrm{Y}=$ Yeast, $\mathrm{F}=$ Fungi. 


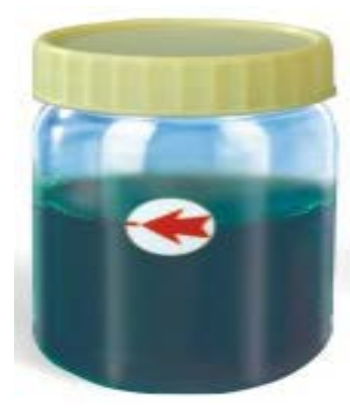

(a)

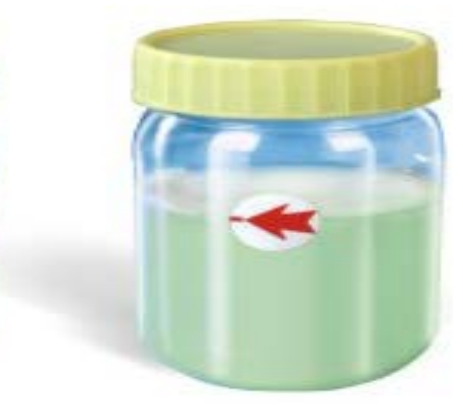

(b)

Figure 3. (a) The black color of the solution due to sulphide by reduction of the sulphite with the Salmonella bacteria; (b) The reagent blank.

Table 1. Physical characteristics of sewage water.

\begin{tabular}{|c|c|c|c|c|c|c|c|c|c|}
\hline S. No. & Location & Area, $\mathrm{km}^{2}$ & Color & $\mathrm{pH}$ & $\begin{array}{c}\mathrm{EC} \\
\mu \mathrm{S} / \mathrm{cm}\end{array}$ & $\begin{array}{c}\mathrm{DO} \\
\mathrm{mg} / \mathrm{mL}\end{array}$ & $\begin{array}{l}\mathrm{RP} \\
\mathrm{mV}\end{array}$ & $\begin{array}{c}\mathrm{TH} \\
\mathrm{mg} / \mathrm{mL}\end{array}$ & $\begin{array}{c}\text { Alk } \\
\mathrm{mg} / \mathrm{mL}\end{array}$ \\
\hline 1 & Gudhiyari & 4 & $\mathrm{BBr}$ & 7.8 & 720 & 7.7 & 168 & 270 & 320 \\
\hline 2 & Bhatagaon & 3 & $\mathrm{BBr}$ & 7.6 & 816 & 7.1 & 161 & 350 & 580 \\
\hline 3 & Saddu Mowa & 4 & $\mathrm{BBr}$ & 7.2 & 1058 & 6.1 & 127 & 390 & 490 \\
\hline 4 & Urla & 4 & $\mathrm{BBr}$ & 6.9 & 1520 & 5.2 & 86 & 350 & 360 \\
\hline 5 & Siltara & 3 & $\mathrm{BBr}$ & 7.4 & 1364 & 7.0 & 107 & 530 & 940 \\
\hline 6 & Heerapur & 2 & BG & 7.2 & 1350 & 7.2 & 337 & 670 & 410 \\
\hline 7 & Pachpedinaka & 2 & BG & 7.6 & 698 & 7.4 & 111 & 570 & 420 \\
\hline
\end{tabular}

$\mathrm{TH}=$ Total hardness, Alk = Alkalinity, $\mathrm{BBr}=$ Blackish brown, $\mathrm{BG}=$ Blackish green.

Table 2. Chemical characteristics of sewage water, mg/L.

\begin{tabular}{|c|c|c|c|c|c|c|c|c|c|c|}
\hline S. No. & $\mathrm{F}^{-}$ & $\mathrm{Cl}^{-}$ & $\mathrm{NO}_{3}^{-}$ & $\mathrm{SO}_{4}^{2-}$ & $\mathrm{PO}_{4}^{3-}$ & $\mathrm{NH}_{4}^{+}$ & $\mathrm{Na}^{+}$ & $\mathrm{K}^{+}$ & $\mathrm{Mg}^{2+}$ & $\mathrm{Ca}^{2+}$ \\
\hline 1 & 1.1 & 31 & 492 & 42 & 9.5 & 134 & 73 & 41 & 13 & 48 \\
\hline 2 & 1.3 & 28 & 512 & 36 & 10.4 & 124 & 136 & 33 & 12 & 50 \\
\hline 3 & 1.4 & 36 & 610 & 48 & 7.4 & 120 & 112 & 30 & 16 & 68 \\
\hline 4 & 1.5 & 31 & 589 & 37 & 8.3 & 115 & 134 & 51 & 13 & 48 \\
\hline 5 & 1.6 & 46 & 485 & 71 & 6.2 & 110 & 137 & 27 & 16 & 80 \\
\hline 6 & 1.3 & 41 & 680 & 49 & 9.1 & 171 & 125 & 48 & 23 & 96 \\
\hline 7 & 0.9 & 48 & 560 & 105 & 7.8 & 128 & 83 & 26 & 18 & 84 \\
\hline
\end{tabular}

Table 3. Contamination levels of sewage water with As and other heavy metals, mg/L.

\begin{tabular}{|c|c|c|c|c|c|c|c|}
\hline Metal & Se1 & Se2 & Se3 & Se4 & Se5 & Se6 & Se7 \\
\hline As & 0.032 & 0.026 & 0.046 & 0.051 & 0.037 & 0.046 & 0.042 \\
\hline $\mathrm{Cr}$ & 0.18 & 0.23 & 0.19 & 0.31 & 0.16 & 0.0 .34 & 0.23 \\
\hline $\mathrm{Mn}$ & 2.1 & 2.7 & 2.5 & 1.8 & 1.6 & 1.7 & 1.5 \\
\hline $\mathrm{Fe}$ & 4.1 & 4.6 & 3.8 & 3.2 & 4.7 & 4.8 & 2.9 \\
\hline $\mathrm{Ni}$ & 0.13 & 0.17 & 0.22 & 0.18 & 0.31 & 0.28 & 0.16 \\
\hline $\mathrm{Cu}$ & $0 . .37$ & 0.45 & 0.52 & 0.61 & 0.48 & 0.38 & 0.54 \\
\hline $\mathrm{Zn}$ & 5.1 & 4.9 & 4.2 & 6.3 & 6.8 & 5.7 & 4.8 \\
\hline Cd & 0.010 & 0.012 & 0.014 & 0.009 & 0.008 & 0.013 & 0.011 \\
\hline $\mathrm{Pb}$ & 0.13 & 0.1 & 0.11 & 0.14 & 0.12 & 0.1 & 0.15 \\
\hline $\mathrm{Hg}$ & 0.004 & 0.004 & 0.006 & 0.007 & 0.009 & 0.004 & 0.005 \\
\hline
\end{tabular}

Se $=$ Sewage . 
Table 4. Microbial contamination levels of sewage water.

\begin{tabular}{cccccc}
\hline S. No. & Location & E. coli + TBC & Pseudomonas + TBC & Yeast + Fungi + TBC & Salmonella \\
\hline 1 & Gudhiyari & $10^{7}$ & $10^{5}$ & $10^{4}$ & Positive \\
2 & Bhatagaon & $10^{6}$ & $10^{6}$ & $10^{6}$ & Positive \\
3 & Saddu Mowa & $10^{7}$ & $10^{7}$ & $10^{6}$ & Positive \\
4 & Urla & $10^{7}$ & $10^{7}$ & $10^{7}$ & Positive \\
5 & Siltara & $10^{7}$ & $10^{6}$ & $10^{7}$ & Positive \\
6 & Heerapur & $10^{6}$ & $10^{6}$ & $10^{4}$ & Positive \\
7 & Pachpedinaka & $10^{6}$ & $10^{6}$ & $10^{5}$ & Positive \\
\hline
\end{tabular}

TBC = Total Bacterial Count (comprises of all the aerobic species of bacteria present in the sample), E. coli= Escherichia coli.

The EC and TH value was observed to be higher than the recommended values reported for the water [22] [23]. The RP value was found to be 4-times less than the recommended value of $650 \mathrm{mV}$ [23].

The concentration of the $\mathrm{F}^{-}, \mathrm{Cl}^{-}, \mathrm{NO}_{3}^{-}, \mathrm{SO}_{4}^{2-}, \mathrm{PO}_{4}^{3-}, \mathrm{NH}_{4}^{+}, \mathrm{Na}^{+}, \mathrm{K}^{+}, \mathrm{Mg}^{2+}, \mathrm{Ca}^{2+}, \mathrm{As}, \mathrm{Cr}, \mathrm{Fe}, \mathrm{Mn}, \mathrm{Ni}, \mathrm{Cu}$, Zn, Cd, Pb and Hg was ranged from 0.9 - 1.6, 28 - 48, 485 - 680, 36 - 105, 6.2 - 10.4, 110 - 171, 73 - 137, 26 51, 12 - 23, 48 - 96, $0.026-0.051,0.16-0.31,1.5-2.7,2.9-4.8,0.13-0.31,0.38-0.61,4.2-6.8,0.008-$ $0.014,0.10-0.15$ and $0.004-0.009 \mathrm{mg} / \mathrm{L}$ with mean value of $1.3 \pm 0.2,37 \pm 6,561 \pm 53,55 \pm 18,8.4 \pm 1.1$, $129 \pm 15,114 \pm 20,37 \pm 8,16 \pm 4,68 \pm 15,0.040 \pm 0.007,0.22 \pm 0.04,2.0 \pm 0.3,4.0 \pm 0.6,0.21 \pm 0.05,0.50 \pm$ 0.06 , $5.4 \pm 0.7,0.011 \pm 0.002,0.12 \pm 0.1$ and $0.006 \pm 0.001 \mathrm{mg} / \mathrm{L}$, respectively. The heavy metal contamination of the water of the studied area was found to be comparable to the Delhi sewage waste water [14]. The observed concentration value of $\mathrm{F}^{-}, \mathrm{NO}_{3}^{-}, \mathrm{Cr}, \mathrm{Mn}, \mathrm{Fe}, \mathrm{Ni}, \mathrm{Cu}, \mathrm{Zn}, \mathrm{Pb}, \mathrm{As}, \mathrm{Cd}$ and $\mathrm{Hg}$ was found to be higher than the reported tolerance limit of 1.0, 45, 0.05, 0.1, 0.3, 0.02, 0.05, 5.0, 0.10, 0.01, 001 and $0.001 \mathrm{mg} / \mathrm{L}$, respectively by agencies i.e. BIS (Bureau of Indian Standards) and WHO (World Health Organization) [22] [23].

The chromatograms of indicative bacteria (i.e. total coliform, E. coli, pseudomonas and salmonella), yeast and fungi are shown in Figure 2 and Figure 3. Their extreme concentrations were observed in all sewage water reservoirs, ranging from $10^{4}$ to $10^{7}$ per $\mathrm{mL}$ Table 4 . The positive test for Salmonella bacteria was marked for all sewage reservoirs. The microbial contamination levels in the sewage water was found to be higher than the microbe contents reported in the water of other region of the country [15]-[21]. The mean WQI value for seven sewage water reservoirs was found to be 191, indicating unsuitability for drinking purpose of the animals, Table 5. The EC, hardness, alkalinity, organic matters, nitrate and microbe levels are main deteriorating components of the sewage waste.

\subsection{Chemical Characteristics of Solid Sewage}

The content of 15 elements in the solid dried sewage samples is presented in Table 6. The concentration of elements i.e. As, P, S, Cl, K, Ca, Cr, Mn, Fe, Ni, Cu, Zn, Cd, Pb and $\mathrm{Hg}$ was ranged from 28 - 41, 414 - 622, 855 1241, 298 - 415, 7704 - 9023, 30,493 - 33,160, 191 - 307, 1096 - 1317, 46,215 - 50,157, 52 - 98, 185 - 389, 429 - 725, $0.23-0.51,89-124$ and $0.15-0.27 \mathrm{mg} / \mathrm{kg}$ with mean value of $34 \pm 54,503 \pm 52,1049 \pm 112,336 \pm 34$, $8120 \pm$ 361, 31,875 \pm 697, $240 \pm$ 32, $1209 \pm$ 64, 48,332 \pm 999, $71 \pm 12,258 \pm$ 58, $549 \pm$ 83, $0.34 \pm$ 0.07, $106 \pm$ 10 and $0.21 \pm 0.03 \mathrm{mg} / \mathrm{kg}$, respectively. The sum of total content of 15 elements (As, P, S, Cl, K, Ca, Cr, Mn, Fe, $\mathrm{Ni}, \mathrm{Cu}, \mathrm{Zn}, \mathrm{Cd}, \mathrm{Pb}$ and $\mathrm{Hg}$ ), $\Sigma_{15 \text { element }}$ in the seven reservoirs was ranged from $98-106 \mathrm{~g} / \mathrm{kg}$ of the dried sewage mass with highest value in the Urla reservoir due to industrial waste input. The concentration of the heavy metals in the reservoirs of the studied area was found to be comparable to other regions of the World [24]-[29].

Among them, the highest content of $\mathrm{Fe}$ followed by $\mathrm{Ca}$ was observed in the sewage waste. The enrichment factor $\left(\mathrm{E}_{\mathrm{f}}\right)$ value of $\mathrm{As}, \mathrm{P}, \mathrm{S}, \mathrm{Cl}, \mathrm{K}, \mathrm{Ca}, \mathrm{Cr}, \mathrm{Mn}, \mathrm{Fe}, \mathrm{Ni}, \mathrm{Cu}, \mathrm{Zn}, \mathrm{Cd}, \mathrm{Pb}$ and $\mathrm{Hg}$ was computed by using their background level in the earth crust with respect to $\mathrm{Al}$ [33]. The mean $\mathrm{E}_{\mathrm{f}}$ value of $\mathrm{As}, \mathrm{P}, \mathrm{S}, \mathrm{Cl}, \mathrm{K}, \mathrm{Ca}, \mathrm{Cr}, \mathrm{Mn}, \mathrm{Fe}$, $\mathrm{Ni}, \mathrm{Cu}, \mathrm{Zn}, \mathrm{Cd}, \mathrm{Pb}$ and $\mathrm{Hg}$ was found to be $54 \pm 6,4.8 \pm 0.6,132 \pm 12,7.1 \pm 0.6,2.8 \pm 0.1,9.7 \pm 0.3,21 \pm 3$, $12.2 \pm$ 0.6, $9.6 \pm 0.4,12 \pm 2,73 \pm 16,64 \pm 10,30 \pm 6,48 \pm 4$ and $33 \pm 5$, respectively. Four elements i.e. S, As, $\mathrm{Cu}$ and $\mathrm{Zn}$ was highly enriched $\left(\mathrm{E}_{\mathrm{f}}=>50\right)$ in the sewage waste. Six metals i.e. $\mathrm{Cr}, \mathrm{Mn}, \mathrm{Ni}, \mathrm{Cd}, \mathrm{Pb}$ and $\mathrm{Hg}$ were 
Table 5. Water quality index of sewage water.

\begin{tabular}{cccccc}
\hline Parameter & Observed mean value & Standard mean value & Unit weight $\left(\mathrm{W}_{\mathrm{n}}\right)$ & Quality rating $\left(\mathrm{q}_{\mathrm{n}}\right)$ & $\mathrm{W}_{\mathrm{n}} \mathrm{q}_{\mathrm{n}}$ \\
\hline $\mathrm{pH}$ & 7.4 & $6.5-8.5$ & 0.219 & 22 & 4.8 \\
$\mathrm{EC}$ & 1075 & 300 & 0.371 & 343 & 127 \\
Alkalinity & 447 & 120 & 0.0155 & 394 & 6.1 \\
Hardness & 503 & 300 & 0.0062 & 143 & 0.9 \\
$\mathrm{Ca}$ & 68 & 75 & 0.025 & 87 & 2.2 \\
$\mathrm{Mg}$ & 16 & 30 & 0.061 & 52 & 3.2 \\
$\mathrm{Cl}$ & 37 & 250 & 0.0074 & 15 & 0.1 \\
$\mathrm{NO}_{3}^{-}$ & 561 & 45 & 0.0412 & 1239 & 51 \\
$\mathrm{SO}_{4}^{2-}$ & 55 & 150 & 0.01236 & 34 & 0.4 \\
$\mathrm{DO}^{-}$ & 6.8 & 4.0 & 0.3723 & 53 & $\Sigma \mathrm{W}_{\mathrm{n}}$ \\
\end{tabular}

Table 6. Concentration of element in solid sewage, $\mathrm{mg} / \mathrm{kg}$.

\begin{tabular}{|c|c|c|c|c|c|c|c|}
\hline Element & Se1 & Se2 & Se3 & Se4 & Se5 & Se6 & Se7 \\
\hline $\mathrm{Al}$ & 9790 & 10,515 & 10,890 & 11,201 & 10,556 & 9876 & 10,471 \\
\hline $\mathrm{P}$ & 414 & 456 & 499 & 517 & 508 & 622 & 503 \\
\hline $\mathrm{S}$ & 855 & 912 & 1014 & 1187 & 1241 & 1087 & 1049 \\
\hline $\mathrm{Cl}$ & 298 & 308 & 317 & 367 & 312 & 336 & 415 \\
\hline $\mathrm{K}$ & 7704 & 7776 & 8150 & 8217 & 9023 & 7850 & 8120 \\
\hline $\mathrm{Ca}$ & 30,493 & 31,215 & 32,189 & 33,160 & 31,670 & 32,416 & 31,857 \\
\hline As & 37 & 32 & 28 & 38 & 41 & 29 & 34 \\
\hline $\mathrm{Cr}$ & 191 & 208 & 216 & 261 & 256 & 307 & 240 \\
\hline $\mathrm{Mn}$ & 1096 & 1130 & 1240 & 1278 & 1190 & 1317 & 1209 \\
\hline $\mathrm{Fe}$ & 46,215 & 47,690 & 48,075 & 49,148 & 48,706 & 50,157 & 48,332 \\
\hline $\mathrm{Ni}$ & 52 & 61 & 74 & 67 & 72 & 98 & 71 \\
\hline $\mathrm{Cu}$ & 185 & 206 & 217 & 236 & 317 & 389 & 258 \\
\hline $\mathrm{Zn}$ & 429 & 468 & 476 & 580 & 614 & 725 & 549 \\
\hline $\mathrm{Cd}$ & 0.31 & 0.23 & 0.29 & 0.29 & 0.36 & 0.40 & 0.51 \\
\hline $\mathrm{Pb}$ & 107 & 98 & 89 & 116 & 124 & 99 & 106 \\
\hline $\mathrm{Hg}$ & 0.24 & 0.19 & 0.15 & 0.19 & 0.23 & 0.17 & 0.27 \\
\hline
\end{tabular}

Se $=$ Sewage

significantly enriched $\left(E_{\mathrm{f}}>10-<50\right)$. Other elements i.e. $\mathrm{P}, \mathrm{Cl}, \mathrm{K}$, Ca and Fe were moderately enriched $\left(\mathrm{E}_{\mathrm{f}}=\leq\right.$ 10 ) in the sewage waste.

\subsection{Correlation Coefficient and Sources}

The species (i.e. $\mathrm{F}^{-}, \mathrm{Cl}^{-}, \mathrm{NO}_{3}^{-}, \mathrm{SO}_{4}^{2-}, \mathrm{PO}_{4}^{3-}, \mathrm{NH}_{4}^{+}, \mathrm{Na}^{+}, \mathrm{K}^{+}, \mathrm{Mg}^{2+}, \mathrm{Ca}^{2+}, \mathrm{As}, \mathrm{Cr}, \mathrm{Fe}, \mathrm{Mn}, \mathrm{Ni}, \mathrm{Cu}, \mathrm{Zn}, \mathrm{Cd}$ and $\mathrm{Pb}$ ) among themselves had either poor or negative correlation in the waste water, indicating origins from the multiple diverse sources. The correlation coefficient matrix for the chemical species (i.e. As, $\mathrm{P}, \mathrm{S}, \mathrm{Cl}, \mathrm{K}, \mathrm{Ca}, \mathrm{Cr}$, $\mathrm{Mn}, \mathrm{Fe}, \mathrm{Ni}, \mathrm{Cu}, \mathrm{Zn}, \mathrm{Cd}, \mathrm{Pb}$ and $\mathrm{Hg}$ ) in the solid waste are presented in Table 7. The ferro alloy elements (i.e. P, $\mathrm{S}, \mathrm{Cr}, \mathrm{Mn}, \mathrm{Ni}, \mathrm{Cu}$ and $\mathrm{Zn}$ ) and $\mathrm{Ca}$ among themselves had good correlations, showing origin from sources i.e. 
Table 7. Correlation matrix of elements in solid sewage waste.

\begin{tabular}{|c|c|c|c|c|c|c|c|c|c|c|c|c|c|c|c|}
\hline & $\mathrm{P}$ & $S$ & $\mathrm{Cl}$ & K & $\mathrm{Ca}$ & As & $\mathrm{Cr}$ & Mn & $\mathrm{Fe}$ & $\mathrm{Ni}$ & $\mathrm{Cu}$ & $\mathrm{Zn}$ & $\mathrm{Cd}$ & $\mathrm{Pb}$ & $\mathrm{Hg}$ \\
\hline $\mathrm{P}$ & 1 & & & & & & & & & & & & & & \\
\hline $\mathrm{S}$ & 0.59 & 1 & & & & & & & & & & & & & \\
\hline $\mathrm{Cl}$ & 0.32 & 0.33 & 1 & & & & & & & & & & & & \\
\hline $\mathrm{K}$ & 0.16 & 0.82 & 0.06 & 1 & & & & & & & & & & & \\
\hline $\mathrm{Ca}$ & 0.71 & 0.71 & 0.51 & 0.26 & 1 & & & & & & & & & & \\
\hline As & -0.35 & 0.40 & 0.01 & 0.57 & -0.15 & 1 & & & & & & & & & \\
\hline $\mathrm{Cr}$ & -0.35 & 0.72 & 0.36 & 0.28 & 0.70 & -0.07 & 1 & & & & & & & & \\
\hline $\mathrm{Mn}$ & 0.91 & 0.64 & 0.44 & 0.17 & 0.91 & -0.34 & 0.85 & 1 & & & & & & & \\
\hline $\mathrm{Fe}$ & 0.95 & 0.74 & 0.39 & 0.31 & 0.82 & -0.19 & 0.95 & 0.91 & 1 & & & & & & \\
\hline $\mathrm{Ni}$ & 0.97 & 0.48 & 0.22 & 0.12 & 0.59 & -0.48 & 0.87 & 0.85 & 0.88 & 1 & & & & & \\
\hline $\mathrm{Cu}$ & 0.90 & 0.60 & 0.16 & 0.33 & 0.41 & -0.10 & 0.92 & 0.67 & 0.83 & 0.89 & 1 & & & & \\
\hline $\mathrm{Zn}$ & 0.93 & 0.71 & 0.30 & 0.33 & 0.60 & -0.02 & 0.99 & 0.78 & 0.92 & 0.87 & 0.96 & 1 & & & \\
\hline Cd & 0.41 & 0.29 & 0.72 & 0.19 & 0.13 & 0.03 & 0.44 & 0.30 & 0.33 & 0.43 & 0.51 & 0.47 & 1 & & \\
\hline $\mathrm{Pb}$ & -0.06 & 0.62 & 0.13 & 0.67 & 0.06 & 0.95 & 0.23 & -0.08 & 0.11 & -0.20 & 0.19 & 0.28 & 0.18 & 1 & \\
\hline $\mathrm{Hg}$ & -0.40 & -0.04 & 0.40 & 0.17 & -0.46 & 0.62 & -0.22 & -0.49 & -0.37 & -0.43 & -0.13 & -0.15 & 0.58 & 0.55 & 1 \\
\hline
\end{tabular}

domestic, industrial and vehicular effluents. Other species had either poor or negative correlations, indicating origin by multiple diverse sources i.e. wasted food materials, leaded pipes, automobile tire rust, vehicular emissions, industrial discharges, runoff water, etc. The major sources of microbes in the sewages are assumed from the human and animal excreta.

\section{Conclusion}

Several chemicals and microbes i.e. heavy metals, nitrate, nutrients, total coliform, Escherichia, pseudomonas, salmonella, yeast and fungi were found to be present in the sewage waste at extremely high levels. The increased prevalence rate of the acute water borne diseases in the summer season is expected due to high multiplication rates of microbes and mixing of the waste with the drinking water supplies i.e. pond, lake, well and shallow tube well. The drinking water contamination could be controlled by improving the sanitary infrastructure with provision of good hygiene system to the population.

\section{Acknowledgements}

We are thankful to the Pt. Ravishankar Shukla University, Raipur, India for providing special UGC equipment grant to the SOS in Environmental Science.

\section{References}

[1] Iannelli, R. and Giraldi, D. (2010) Sources and Composition of Sewage Effluent; Treatment Systems and Methods. In: Levy, G.J., Fine, P. and Bar-Tal, A., Eds., Treated Wastewater in Agriculture: Use and Impacts on the Soil Environment and Crops, Wiley-Blackwell, Oxford.

[2] Davis, R.D., Hucker, G. and L'Hermite, P. (1983) Environmental Effects of Organic and Inorganic Contaminants in Sewage Sludge. Springer, Berlin.

[3] Harrison, E.Z., Oakes, S.R., Hysell, M. and Hay, A. (2006) Organic Chemicals in Sewage Sludges. Science of the Total Environment, 367, 481-497. http://dx.doi.org/10.1016/j.scitotenv.2006.04.002

[4] Clarke, B.O. and Smith, S.R. (2011) Review of ‘Emerging’ Organic Contaminants in Biosolids and Assessment of International Research Priorities for the Agricultural Use of Biosolids. Environment International, 37, 226-247. 
http://dx.doi.org/10.1016/j.envint.2010.06.004

[5] Smith, S.R. (2009) A Critical Review of the Bioavailability and Impacts of Heavy Metals in Municipal Solid Waste Composts Compared to Sewage Sludge. Environment International, 35, 142-156.

http://dx.doi.org/10.1016/j.envint.2008.06.009

[6] Smith, S.R. (2009) Organic Contaminants in Sewage Sludge (Biosolids) and Their Significance for Agricultural Recycling. Philosophical Transactions of the Royal Society A Mathematical Physical and Engineering Sciences, 367, 4005-4041. http://dx.doi.org/10.1016/j.envint.2008.06.009

[7] Schowanek, D., Carr, R., David, H., Douben, P., Hall, J., Kirchmann, H., Patria, L., Sequi, P., Smith, S. and Webb, S. (2004) A Risk-Based Methodology for Deriving Quality Standards for Organic Contaminants in Sewage Sludge for use in Agriculture-Conceptual Framework. Regulatory Toxicology Pharmacology, 40, 227-251. http://dx.doi.org/10.1016/j.yrtph.2004.07.002

[8] Harrison, E.Z., Oakes, S.R., Hysell, M. and Hay, A. (2006) Organic Chemicals in Sewage Sludge. Science of the Total Environment, 367, 481-497. http://dx.doi.org/10.1016/j.scitotenv.2006.04.002

[9] Cheng, H.F., Chen, S.Y. and Lin, J.G. (2001) Hazardous Organic Matters in Municipal Sewage Sludge in Taiwan. Water Science and Technology, 44, 65-70.

[10] Petrović, M. and Barceló, D. (2000) Determination of Anionic and Non-Ionic Surfactants, Their Degradation Products, and Endocrine-Disrupting Compounds in Sewage Sludge by Liquid Chromatography/Mass Spectrometry. Analytical Chemistry, 72, 4560-4567. http://dx.doi.org/10.1021/ac000306o

[11] Andersen, H., Siegrist, H., Halling-Sørensen, B. and Ternes, T.A. (2003) Fate of Estrogens in a Municipal Sewage Treatment Plant. Environmental Science and Technology, 37, 4021-4026. http://dx.doi.org/10.1021/es026192a

[12] Davis, E.F., Klosterhaus, S.L. and Stapleton, H.M. (2012) Measurement of Flame Retardants and Triclosan in Municipal Sewage Sludge and Biosolids. Environment International, 40, 1-7. http://dx.doi.org/10.1016/j.envint.2011.11.008

[13] Kim, M., Guerra, P., Theocharides, M., Barclay, K., Smyth, S.A. and Alaee, M. (2013) Polybrominated Diphenyl Ethers in Sewage Sludge and Treated Biosolids: Effect Factors and Mass Balance. Water Research, 47, 6496-6505. http://dx.doi.org/10.1016/j.watres.2013.08.022

[14] Maheshwari, S., Joshi, P.K., Kumar, R. and Singh, N. (2008) A Study of Heavy Metals in Sludge, Sewage and Industrial Waste Water of Different Districts of Haryana. Current World Environment, 3, 93-96.

[15] Rawat, V., Jha, S.K., Bag, A., Singhai, M. and Rawat, C.M. (2012) The Bacteriological Quality of Drinking Water in Haldwani Block of Nainital District, Uttarakhand, India. Journal of Water and Health, 10, 465-470. http://dx.doi.org/10.2166/wh.2012.035

[16] Mukhopadhyay, C., Vishwanath, S., Eshwara, V.K., Shankaranarayana, S.A. and Sagir, A. (2012) Microbial Quality of Well Water from Rural and Urban Households in Karnataka, India: A Cross-Sectional Study. Journal of Infection and Public Health, 5, 257-562. http://dx.doi.org/10.1016/j.jiph.2012.03.004

[17] Anand, C., Akolkar, P. and Chakrabarti, R. (2006) Bacteriological Water Quality Status of River Yamuna in Delhi. Journal of Environmental Biology, 27, 97-101.

[18] Suthar, S., Chhimpa, V. and Singh, S. (2009) Bacterial Contamination in Drinking Water: A Case Study in Rural Areas of Northern Rajasthan, India. Environmental Monitoring and Assessment, 159, 43-50. http://dx.doi.org/10.1007/s10661-008-0611-0

[19] Kumar, S., Tripathi, V.R. and Garg, S.K. (2012) Physicochemical and Microbiological Assessment of Recreational and Drinking Waters. Environmental Monitoring and Assessment, 184, 2691-2698. http://dx.doi.org/10.1007/s10661-011-2144-1

[20] Chitanand, M.P., Gyananath, G. and Lade, H.S. (2008) Bacterial Assessment of Ground Water: A Case Study of Nanded City. Journal of Environmental Biology, 29, 315-318.

[21] Krishnan, R.R., Dharmaraj, K. and Ranjitha Kumari, B.D. (2007) A Comparative Study on the PhysicoChemical and Bacterial Analysis of Drinking, Borewell and Sewage Water in the Three Different Places of Sivakasi. Journal of Environmental Biology, 28, 105-108.

[22] BIS (2009) Drinking Water-Specification. 2nd Edition, Bureau of Indian Standards, New Delhi.

[23] WHO (2011) Guidelines for Drinking-Water Quality, 4th Edition. World Health Organization, Switzerland.

[24] Huang, H.J., Yuan, X.Z., Zeng, G.M., Zhu, H.N., Li, H., Liu, Z.F., Jiang, H.W., Leng, L.J. and Bi, W.K. (2011) Quantitative Evaluation of Heavy Metals' Pollution Hazards in Liquefaction Residues of Sewage Sludge. Bioresource Technology, 102, 10346-10351. http://dx.doi.org/10.1016/j.biortech.2011.08.117

[25] Yuan, X.Z., Huang, H.J., Zeng, G.M., Li, H., Wang, J.Y., Zhou, C.F., Zhu, H.N., Pei, X.K., Liu, Z.F. and Liu, Z.T. (2011) Total Concentrations and Chemical Speciation of Heavy Metals in Liquefaction Residues of Sewage Sludge. Bioresource Technology, 102, 4104-4110. http://dx.doi.org/10.1016/j.biortech.2010.12.055 
[26] Pathak, A., Dastidar, M.G. and Sreekrishnan, T.R. (2009) Bioleaching of Heavy Metals from Sewage Sludge: A Review. Journal of Environmental Management, 90, 2343-2353. http://dx.doi.org/10.1016/j.jenvman.2008.11.005

[27] Prechthai, T., Parkpian, P. and Visvanathan, C. (2008) Assessment of Heavy Metal Contamination and Its Mobilization from Municipal Solid Waste Open Dumping Site. Journal of Hazardous Materials, 156, 86-94. http://dx.doi.org/10.1016/j.jhazmat.2007.11.119

[28] Souza, L.C.F., Canteras, F.B. and Moreira, S. (2014) Analyses of Heavy Metals in Sewage and Sludge from Treatment Plants in the Cities of Campinas and Jaguariúna, Using Synchrotron Radiation Total Reflection X-Ray Fluorescence. Radiation Physics and Chemistry, 95, 342-345. http://dx.doi.org/10.1016/j.radphyschem.2013.01.025

[29] Al-Musharafi, S.K., Mahmoud, I.Y. and Al-Bahry, S.N. (2013) Heavy Metal Pollution from Treated Sewage Effluent. APCBEE Procedia, 5, 344-348. http://dx.doi.org/10.1016/j.apcbee.2013.05.059

[30] APHA (2005) Standard Methods for Examination of Water and Waste Water. 21st Edition, AHPA, Washington DC.

[31] IAEA-TECDOC-1360 (2003) Collection and Preparation of Bottom Sediment Samples for Analysis of Radionuclides and Trace Elements.

[32] Rakiro Biotech System Pvt. Ltd. (2008) Bactaslyde Microbe Detection Device, ISO 9001, Mumbai, India. www.rakiro.net

[33] Rudnick, R.L. and Gao, S. (2003) The Composition of the Continental Crust. In: Rudnick, R.L., Ed., The Crust, Vol. 3, Holland, H.D. and Turekian, K.K., Eds., Treatise on Geochemistry, Elsevier-Pergamon, Oxford, 1-64. 